\title{
La educación debe traspasar las fronteras del entramado mundo
}

\author{
Education Must Straddle the Borders of this Tangled World \\ A educação deve ir além dos limites do quadro mundial
}

\author{
María del Carmen Gutiérrez Agudelo'
}

DOI: 10.5294/aqui.2018.18.2.1

Actualmente, la educación sigue nadando a contracorriente; se continúa con la alineación de los estudiantes, se repite la misma información o la que se encuentra en los medios de comunicación (libros, internet, bases de datos, manuales), se fragmentan las asignaturas y se obliga a que todos y todas aprendan igual, por lo que se acorta en los y las aprendices el pensamiento y se inhibe su creatividad, aferrados a un sistema obsoleto, rígido y arbitrario. Sin embargo, existen posturas que trazan lineamientos en contra de lo anterior, donde se describe que la educación debe reorientarse hacia los intereses y las necesidades de los educandos y las educandas, teniendo en cuenta el contexto, la cultura, el ambiente y los avances tecnológicos, aspectos que muchas instituciones ya han ido incorporando en su proceso educativo, pues se vislumbra un futuro del que no podemos alejarnos y al que debemos dar respuestas razonadas y deliberadas para hacer frente a las incertidumbres y controversias, a fin de poder contribuir a protagonizar la transformación social que se nos exige.

Por ello, al enfrentar nuestros retos, hacemos eco de las propuestas de Julián de Zubiría en su reciente publicación Los desafíos de la educación colombiana (1), donde se habla de rediseñar el sistema, inventar y pensar nuevas formas para interactuar con los otros y las otras en los encuentros del acto educativo, con nuevas estrategias que involucren el trabajo en equipo, colabora-

1 orcid.org/0000-0002-8403-2768. Universidad de La Sabana, Colombia. mariac.gutierrez@unisabana.edu.co tivo, la interacción respetuosa intercultural e inclusiva, donde se tengan en cuenta la cultura, los valores y la ecología como ejes integradores de la vida de los seres humanos.

Ante esto nos tenemos que cuestionar permanentemente: ¿será que reproducimos en nuestra enseñanza lo tradicional, apegados al pasado mecánico y condicionados por la fragmentación y desintegración del conocimiento? ¿0 enseñamos lo que necesitan nuestros educandos, enfocados hacia sus intereses y expectativas? ¿Por qué no desechar esas ideas obsoletas de que solo se aprende a partir de la memoria y la repetición, con bastante información descontextualizada? ¿0 será que el sistema ha condicionado la actuación y no ha permitido en los maestros 0 mediadores la reflexión pedagógica acerca de su quehacer? Y por último vale la pena preguntarse, ¿quién formará a los educadores y las educadoras?

Estos interrogantes requieren que repensemos la educación que brindamos, que nos cuestionemos, que proyectemos ese cambio paradigmático emergente, donde se enfoque la educación hacia nuevos caminos flexibles y abiertos; donde se desarrolle el pensar, hacer y sentir, apoyados en la afectividad, la ética y la estética. Donde la apertura, la incertidumbre, la imprevisibilidad, el diálogo y la búsqueda del saber sean la base para llegar a "resignificar", es decir para dar sentido a lo que se hace en ese encuentro o mediación pedagógica, que conduzca a dar significado al mundo y a las propias experiencias de los y las interactuantes. 
Esta propuesta, enfocada a la formación del enfermero(a), se debe orientar hacia el uso de estrategias o modelos de clase y de práctica donde se propicien las experiencias de cada participante y se exploten al máximo sus potencialidades, para que en conjunto con los otros, en esa red de interconexión, encuentren el sentido de lo que hacen, sean auténticos críticos, verdaderos creativos, y se comprometan a trabajar en beneficio de todos y todas, sin abandonar su contexto.

Para ello, en los encuentros mediadores en el aula o fuera de ella se deben utilizar estrategias generadoras o actividades de aprendizaje que involucren la experiencia individual, social y cósmica, donde exista correlación entre la realidad que nos habla, y la creatividad y el interés por hacer hablar dicha realidad. Por ejemplo, tener en cuenta los aconteceres de cada día, ordinarios o extraordinarios, como un nacimiento, la enfermedad de un familiar, de un amigo; una experiencia hospitalaria o un tratamiento, así como las realidades analizadas, transformadas, codificadas y señaladas por científicos, escritores, poetas o pintores: artículos publicados, una poesía, textos sobre una teoría de cuidado, imágenes de hospitales, unidades o servicios de pacientes, epidemias o situaciones de enfermedades, entre otras.

Existe otro aspecto que no debemos olvidar, y es la práctica simulada, para que los avances y recursos tecnológicos que hoy se usan lleven a la formulación de preguntas, a definir un problema 0 situación, a buscar evidencias, a analizar diferentes alternativas de solución, y a tolerar las ambigüedades o los sesgos presentes. Ya que en la práctica profesional estos retos se deben enfrentar con capacidad de crítica, con mente abierta, a partir de razonamientos y juicios reflexivos, honestos y prudentes basados en el hacer y el actuar.

Con estas experiencias de aprendizaje se busca el protagonismo de los y las participantes, la armonía entre el sentir y la razón, se provoca el sabor del saber, se despiertan el interés y la continuidad, se crean relaciones con el contexto que ayudan a transformar la realidad. El énfasis se debe poner en el acto de aprender, es decir en la autoorganización del conocimiento que cada ser humano debe ejecutar.

Pero, igualmente, se necesitan educadores y educadoras con identidad, perspectiva ética, racional y cognoscitiva; promotores de valores, maestros de vida que enseñen a vivir. Que sean además creadores de nuevos conocimientos y visiones del mundo, diseñadores de ambientes educativos que involucren las tecnologías de la información y la comunicación.

En la Asociación Colombiana de Facultades y Escuelas de Enfermería (Acofaen), cuya misión se enfoca en fortalecer la formación del profesional de enfermería en Colombia, las perspectivas en educación se alinearán hacia la formación de profesionales con sentido humano, con responsabilidad social, capacidad para tomar decisiones y buscar soluciones dentro del equipo multidisciplinario en el cual interactúan, liderando el cuidado de la persona, la familia y la comundiad en el contexto donde ejerzan su quehacer profesional.

Para concluir citamos a Francisco Gutiérrez, quien señala: "Hay que educar para las épocas futuras, no para las que se fueron" y "El presente, lo dejó escrito el maestro, es la gravitante transformación del pasado en futuro" (2).

\section{Referencias}

1. Samper J. Los desafíos de la educación colombiana. 2017. Disponible en: http://www.semana.com/educacion/articulo/ plan-decenal-los-retos-de-la-educacion-en-colombia/534554

2. Gutiérrez F. Omar Dengo educador de un pueblo. 2a ed. Costa Rica: Editorial Nueva Década; 1986.94 p. 